University for Business and Technology in Kosovo

UBT Knowledge Center

UBT International Conference

2015 UBT International Conference

Nov 7th, 9:00 AM - 5:00 PM

\title{
The impact of budget deficit on inflation An econometric approach for the period $1994-2012$
}

\author{
Ardit Gjeçi \\ Alpha Bank Albania, ardit_ubt@hotmail.com \\ Juljan Hysa \\ Agricultural University of Tirana, juljan.hysa@hotmail.com
}

Follow this and additional works at: https://knowledgecenter.ubt-uni.net/conference

Part of the Business Commons

\section{Recommended Citation}

Gjeçi, Ardit and Hysa, Juljan, "The impact of budget deficit on inflation An econometric approach for the period 1994 - 2012" (2015). UBT International Conference. 37.

https://knowledgecenter.ubt-uni.net/conference/2015/all-events/37

This Event is brought to you for free and open access by the Publication and Journals at UBT Knowledge Center. It has been accepted for inclusion in UBT International Conference by an authorized administrator of UBT Knowledge Center. For more information, please contact knowledge.center@ubt-uni.net. 


\title{
The impact of budget deficit on inflation An econometric approach for the period $1994-2012$
}

\author{
Ardit Gjeçi ${ }^{1}$, Juljan Hysa ${ }^{2}$ \\ ${ }^{1}$ Risk Management Department, Alpha Bank Albania, \\ ${ }^{2}$ Agricultural University of Tirana \\ ardit_ubt@hotmail.com¹,juljan.hysa@hotmail.com²
}

\begin{abstract}
The aim of research is to define and explain a relation between macroeconomic indicators such as the budget deficit and inflation. Under consideration is taken the period between 1994-2012, a period which has had an intensity and greater attention by the internationals in terms of performance of the economy. The paper studies these indicators mainly through econometric model, by considering indicators a function of each other. Main hypothesis of this research is: "If we increase the budget deficit and money supply, the rate of inflation is expected to increase." Based on the inflation model only in relation with money supply, it results a positive results, this only for the money supply with a dynamic delay of 1 . The opposite dynamic results without delay. In the extended model of inflation, its connection with the budget deficit, not only comes out as negative, but the level of determination for this relationship is very low. This has no theoretical consistency and, most importantly, is a very unclear link between these two indicators.
\end{abstract}

Keywords: budget deficit, inflation, money supply

\section{Research Problem}

\subsection{General Issue}

The budget deficit and inflation are two of several aspects and main economic indicators in a country, whether developed, transitional or underdeveloped. They are the main target to which focuses the attention of governments to improve the economy in general and financial public sector in particular. Albania, as a developing country, is very sensitive to these macroeconomic indicators. The main goal of any government, especially in these last 10 years, has been keeping an optimum level and as low as possible, budget deficit, as well as achieving a stable and moderate stage of inflation rate. These indicators were given special attention, especially after the start of different procedures and integration agreements in EU membership. A great emphasis was given by internationals, to the level of public debt, which according to them should not exceed from the optimal line, this one as this form of preventing a further increase of budget deficit. Taking this into account, in 2006, Albania issued the law of public debt, which among other thing, stated that the GDP should not exceed a level of $60 \%$. Despite the law of 2006, the government in 2013 went beyond $60 \%$ of public debts because of this a change was made in the law. This one was as a motivation form to finance the budget deficit, although skeptics believe that debt was used more for the purpose of election expenses.

On the other hand inflation has been maintained at moderate rates, regardless of fluctuations in some specific periods. Problems in the academic field, regarding these two important indicators in the economy is that still there are not enough empirical studies, or theoretical Albanian scholars, focusing on the existence or not of a link between the budget deficit and inflation. Perhaps this is one of the reasons why our country governments have not taken adequate measures to prevent the growth of the budget deficit and its impact on inflation. This problem would have been more lighten if some effort was made from theoretical studies of interaction of these phenomena with very significant impact our economy. 


\subsection{Research Issue}

The issue we want to be addressed in this paper is pointing out the existence or not of an interaction between the budget deficit, money supply and inflation in our country. Based on some economic theories, of some foreign authors who have studied the relationship and influence between these two indicators, we seek to treat theoretical and empirical implications of inflation budget deficit for the period 1994 - 2012 in Albania.

The existence of a causal link, based on empirical data, will enable clarification of this issue, it will motivate further studies about this issue and what is more important will enable the design of suitable policies by the government for controlling the budget deficit and inflation, thus helping to reduce the public debt and improving the money supply, increasing welfare and consumer purchasing power.

Money supply is related to the theory of Milton Friedman, which means that inflation is everywhere where there is a monetary phenomenon. The theory explains that the continuous increase in prices is followed by a specific increase in the money supply. The expectation is that a state budget with deficit at a certain time must be careful with the outstanding amounts issued, in order to avoid a budget surplus in the future.

Relationship budget deficit - inflation is also discussed considering the direct effect of inflation on debt, tax revenues and possible extensions.

Dynamic interaction of budget deficit and inflation can go in two directions:

- $\quad$ The effect of inflation can reduce the real value of dominant debt, or

- Inflation may worsen the fiscal position of the state.

The decline in revenue is accepted as a contributing factor in the inflationary process by increasing the money supply to finance the deficit inflationary.

Empirical work on the relationship between budget deficit and inflation has given conflicting results. However the cause of the direction is resulted to be from deficit to inflation, which is empirical evidence and for this fact is still not a definitive conclusions (Abizadeh \& Yousefi, 1998; Hondroyiannis \& Papapetrou, 1997; Barnhart \& Darrat, 1988; Ahking \& Miller, 1985; Dwyer, 1982; Hamburger \& Zwick, 1981).

It seems that the relationship "budget deficit - inflation" actually shows a two-way interaction, meaning; not only that the budget deficit through its impact brings inflationary pressure but also has a subsequent effect by increasing the budget deficit. The problem lies in the fact that duties (taxes) are paid late and not on the date stated. In function of these delays, high inflation reduces the difficulty in collecting taxes. In this case we have a budget deficit that leads to higher inflation which reduces the real income from taxes; real reduction of tax revenues will again bring the budget deficit, and so on will continue the cycle. Chaudhary and Ahmad (1995) suggest that domestic financing of the budget deficit, especially from the banking system, is inflationary in the long run. The results give a positive correlation between the budget deficit and inflation during acute periods of inflation. Idress and Khan (2006) examined the relationship between the budget deficit and inflation. The deficit was financed by the issuance of a new currency, borrowing from the banking and non-banking institutions or international financial institutions. All this increases the flow of money in the economy and then turns into inflation. Theoretical studies made for the relation: budget deficit - inflation (Sargence \& Wallance 1985) have shown that if the budget deficit is not funded or will not be funded in the future, prices will rise. These studies have also proven that if state debt becomes unbearable, the budget deficit will have a tendency to lead to inflation. An adjustment to the budget deficit to eliminate the inflation can be successful and make this relationship a positive one, if the study will be made simultaneously for both phenomenons.

As stated above, we may ask some questions:

- $\quad$ Is budget deficit a good indicator?

- What are the ways to keep the deficit low in order to maintain stable inflation?

- $\quad$ Is it better that the deficit be financed by issuing currency, borrowings, increase revenues through taxes or spending cuts? 


\section{Literature review}

In this part we will take a general looks how others have treated the relationship between these indicators. But we came across a large barrier about finding studies for Albania.

According to Bruno (1995), a higher inflation rate is accompanied by serious imbalances in public finances. His detailed analysis shows that in all cases of inflationary crisis, the country showed large budget deficits before the crisis, much more prevalent during the crisis and on average during recovery after crisis. Empirical observation confirms the monetarist assumption that budget deficits contribute to the growth of money supply and that excessive creation of money is responsible for inflation. Montiel (1989), supporters of the budget approach and in particular Milton Friedman, support the idea that inflation is always and everywhere a monetary phenomenon. Theoretical contributions of Sargance and Wallace (1981), Dornbusch (1985 and 1992), Buiter (1984), Van Wijnberge Anand (1987 and 1989), and also Dornbusch and Fischer (1989) have shown that permanent expansion of monetary originally comes from budgetary imbalances. However, empirical work does not always lead to this conclusion.

For Barro (1978) is the increasing of public spending that increases the money supply, not the amount of the budget deficit. However, American experience offers ambivalent results. Dual meaning of a link between money supply growth and public finance imbalances continues in the works dedicated to other developed economies. Thus, Kolluri and Giannaros (1985), Protopapadakis and Siegel (1986) have tested a similar model to that of Barro for ten industrialized countries.

However, they do not find a significant link between the budget deficit and money supply growth. In contrast, for the same countries, Blundell and Chouraqui (1981) found that the acceleration of money supply growth coincides with a number of countries that implement expansionary budget policies. Conflicting results were obtained by the researchers also in the developing countries. For economists the main cause that does not bring meaningful positive relationship between public finance imbalances, increasing the money supply and the inflation rate is the method of financing the budget deficit. As a rule, sales of debt securities of private sector non-bank public or external financing (in the case of exchange rate fluctuations) provide non-monetary financing of budget deficit.

According to Modigliani (1987) the link between the amounts of budget deficits and money supply growth is not true at least for economies with a developed financial system.

However, it is acknowledged that monetary financing is inflationary because it causes an increase in the money supply. And in many developing countries and countries in transition, inflationary pressure is different from what is observed in industrialized countries and in countries with rapid expansion, because of the important role played by budget deficit, limited development of domestic financial markets, as well as restrictions on the use of external financing. Due to the narrowing of domestic financial markets, the financing through money creation remains a privileged way or the last way, through which the Treasury can obtain the necessary funds. Hyperinflation and inflation pressures are highlighted chronic in many countries that have large budget deficits flows.

\section{Research Hypothesis}

Main hypothesis of this research is: increase."

"If we increase the budget deficit and money supply, the rate of inflation is expected to

Alternative hypotheses:

"If we increase the budget deficit and the economic growth rate, the money supply is expected to increase."

"If you increase the money supply, the inflation rate is also expected to increase." 


\section{Methods and Procedures}

Project scheme is as follows:

The purpose of this paper is to identify whether there is a link between the budget deficit and inflation, and is this stable connection in the period 1994-2012. To better see the connection we have taken into consideration and the money supply which serves as a bridge for both of them.

The scale of the problem formulation is not high, given that exist the lack of a suitable theoretical approach to justification of the link between indicators. There is only one work by Milo $(2012)^{26}$, where we are based fro building an econometric model.

Data for the study were secondary data and were obtained from official sources such as the World Bank for the inflation rate, the rate of GDP and money supply; this is because only here we could find the data for the years 1994-2012. As for the budget deficit we used for the study, INSTAT 27 data. These data are time series because the variable annual budget deficit is published once a year. The conclusions will be based on the study that will be performed on the data obtained from the above. Concepts:

1. The budget deficit is the negative difference between income and expenditure, when budget expenditures are higher than budget revenues. The revenues aren't realized because, not all taxpayers are correct with the law and avoid obligations to pay; due to difficulties in collecting taxes; due to social policy that follows the country etc. Costs are high because of the high amount of public investments.

2. Inflation is the stable and sustainable growth of prices, which comes always and anywhere as a monetary phenomenon caused by the surplus of money in relation to product release. It is measured by the Consumer Price Index (CPI) and it comes as the result of excessive growth of aggregate demand in relation to aggregate supply.

3. $\quad$ M2 is called broad money, which includes M1 and other forms of assets that are not money transactions, but that can rapidly return into money, such as short-term deposits, mutual funds of monetary markets accounts.

4. Real GDP which expresses the value of goods and services measured at fixed price. This is the most accurate measure of country's economic welfare.

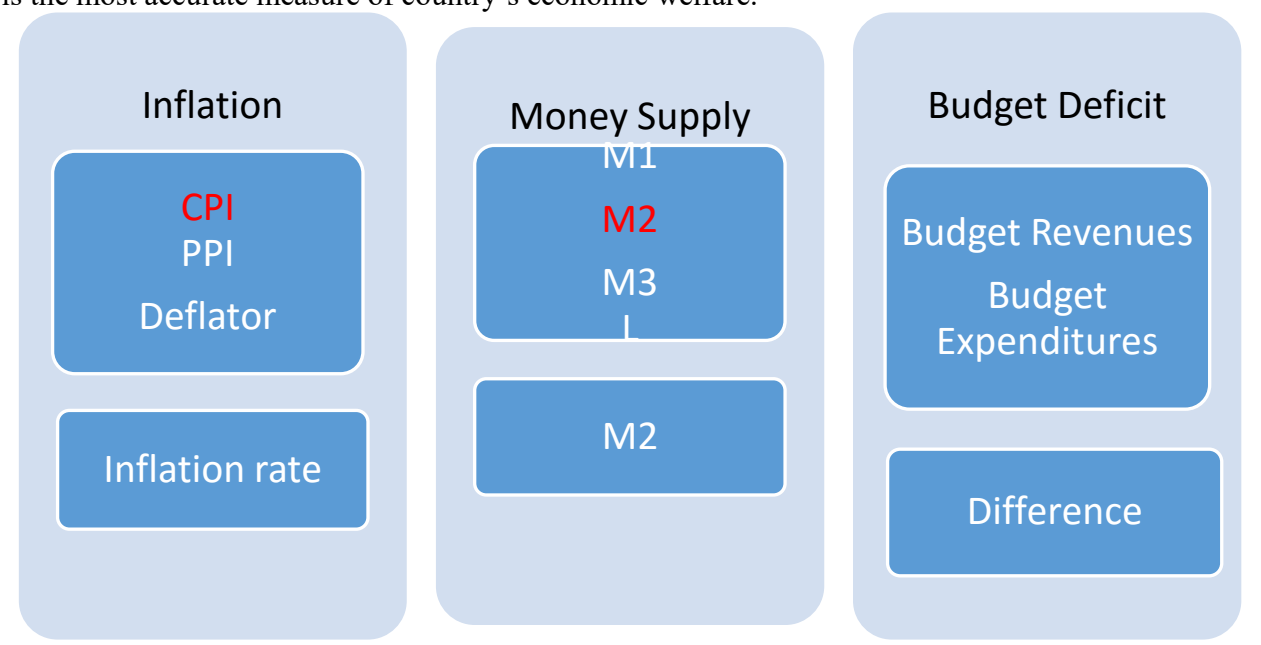

Model tries to highlight the impact of budget deficit and money supply growth and inflation rate. Albania is known as a country in transition and study where we trust more is Milo (2012), which has study precisely transition countries like Romania, Bulgaria and Albania.

The model starts with two basic equations:

1. The money supply growth equation.

2. The inflation equation.

The reduced form of growth rate of money supply that we have used is specified as follows:

26 "The impact of budget deficit on the currency and inflation in the transition economies"

${ }^{27}$ Albanian Institute of Statistics and Database 


$$
m_{t}=a_{0}+\sum_{k=1}^{n} a_{1} m_{t-k}+\sum_{k=1}^{n} a_{2} d_{t-k}+\sum_{k=1}^{n} a_{3} y_{t-k}
$$

$\mathrm{k}=1,2 \ldots . \mathrm{n}$

$\mathrm{m}_{\mathrm{t}}=$ annual growth rate of money supply

$\mathrm{d}_{\mathrm{t}}=$ budget deficit

$\mathrm{y}_{\mathrm{t}}=$ growth rate of GDP

The impact of the budget deficit on inflation analysis is to specify an equation base of price change, which would explain inflation ranging from money supply growth. In our analysis, we used a monetarist equation price which differs as follows (Giannaros and Kolluri, 1985):

$$
\pi_{t}=b_{0}+\sum_{k=1}^{n} b_{1} m_{t-k}
$$

$\mathrm{k}=1,2 \ldots \mathrm{n}$

$\mathrm{t}=$ inflation rate

In equation (2) the actual inflation rate depends on the current and past rates of money supply. Equation (2) allows us to measure the effect of monetary expansion on inflation. In other words, it measures the impact of excessive money creation in connection with the financing of the budget deficit. But this does not allow us to identify the effect of other factors on the inflation rate, meaning, the contribution of the same amount of budget deficit and the contribution of inertial inflation.

Here we have added two other variables such as the budget deficit that allows capturing the impact of aggregate demand growth in prices due to high budget deficit, and then the inflation rate with dynamic delay which allows capturing the effects of inertia. We have taken an equation formulated as follows:

$$
\pi_{t}=b_{0}+\sum_{k=0}^{n} b_{1} m_{t-k}+\sum_{k=0}^{n} b_{2} d_{t-k}+\sum_{k=1}^{n} b_{3} \prod_{t-1}
$$

$\therefore \mathrm{t}=$ actual inflation rate, which depends on the growth of money supply, increased budget deficit and delayed inflation

\section{Evaluations and interpretations}

$$
\begin{aligned}
& m=16888207600+1.01 * m(-1)+0.06 * m(-2)+120.34 * d+364.34 * \\
& d(-1)+345.43 * d(-2)+1445373809 * y+1871429250 * y(-1)+ \\
& 355580475 * y(-2) \quad(1)
\end{aligned}
$$

\section{$\mathrm{R}^{2}=\mathbf{0 . 9 9}$ Prob $(\mathrm{F}$-statistic $)=\mathbf{0 . 0 0 0 0 0 0}$}

Based on the assessment by E-views money supply model about the budget deficit and economic growth, we managed to conclude that an increase in the budget deficit and an increase in the level of economic growth lead to a money supply growth. The coefficient of determination shows that $99 \%$ of the variance of money supply depends on the variation of the budget deficit and economic growth. So, we are dealing with a very good model.

$$
\begin{gathered}
\pi=16.95-2.16 e-10 * m+1.762672458 e-10 * m(-1) \\
\mathrm{R}^{2}=\mathbf{0 . 3 1} \quad \text { Prob }(\text { F-statistic })=\mathbf{0 . 0 5 8 5 7 7}
\end{gathered}
$$

The relationship between inflation and money supply is positive, based on economic logic, so we can say that is a proven link. For this reason the connection will serve as a "bridge" to prove the link between inflation and the deficit in equation (3). So, in equation (1) it appears that the increase in deficit will increase the money supply, which the latter leads to an increased inflation. 
For Albania case, relationship between inflation and money supply turns out to be inconsistent with the theory, because of "non-existence of the state" in before years ' 99 , the not function private sector and the almost nonexistent activity of the banking sector. For this reason we built a model for the period 1999-2012, which is estimated as follows:

$$
\begin{gathered}
\log \pi=-47.98+1.86 * \log m \\
\left.\mathrm{R}^{2}=\mathbf{0 . 3 4} \quad \text { Prob(F-statistic }\right)=\mathbf{0 . 0 2 6 9 2 2}
\end{gathered}
$$

This model is consistent with the theory because the value $\operatorname{Prob}(\mathrm{F}$-statistic $)<0: 05$

On the basis of economic logic, connection between inflation and a deficit must come about a straight one, but for the reasons mentioned above result it appears below:

$$
\begin{gathered}
\pi=13.074-2.166749269 e-10 * m+1.845844803 e-10 * m(-1)-1.677732553 e- \\
07 * d+1.3835206 e-07 * d(-1)+0.14 * \pi(-1)
\end{gathered}
$$

$\mathrm{R}^{2}=\mathbf{0 . 4} \quad$ Prob(F-statistic $)=\mathbf{0 . 2 3 2 6 7 7}$

So, as we can see for the period 1994 - 2012, the extended model, the relationship between the budget deficit and inflation turns out to have not a clear link.

\section{Conclusions and recommendations}

The growth of the budget deficit and increase the level of economic growth leading to increased money supply. This connection results to be a very strong one and in full consistency with economic logic, with (1) of (2) dynamic delays of variables. Based on the inflation model only in relation with money supply, it results a positive results, this only for the money supply with a dynamic delay of 1 . The opposite dynamic results without delay.

Completely logical link results for logarithmic model (2.1), which expresses the positive relationship between inflation and money supply.

In the extended model of inflation, its connection with the budget deficit, not only comes out as negative, but the level of determination for this relationship is very low. This has no theoretical consistency and, most importantly, is a very unclear link between these two indicators.

We recommend that further studies be constantly connected to the above problems, to have a clearer picture of the impact and consistency of the budget deficit on inflation.

We hope and believe that the more research done to study this issue, the more it will be helpful to the expansion and materialization of economic theory and practice. This will help stakeholders to develop concrete and safe policies for the budget deficit and inflation, as an interactive indicator of each other. However, we hope that our research can draw the attention of researchers in this field, by proceeding with other studies that will enrich the empirical and scientific studies for Albania. 


\section{References}

1. Osmani, M. (2013). Metodat e Ekonometrisë me Eviews.

2. Salko, D. Dhuci, O. (2005). Paraja dhe Institucionet Financiare.

3. Skreli, E. Cera, E. (2013). Metodologjia e kerkimit ne ekonomine e zbatuar.

4. Boariu, A. Bilan, I. (2007). Inflationary effects of budget deficits financing on contemporary economies. Romania: Alexandru Ioan Cuza University.

5. Milo, P. (2012). The impact of the budget deficit on the currency and inflation in the transition economies.

6. Neyapti, B. (2003). Budget deficits and inflation: The role of Central Bank Indipendence and Financial Market Development. Western Economic Association International.

7. Solomon, M. Wet, W. (2004). The effect of a budget deficit on inflation: The case of Tanzania. Tanzania, South Africa: University of Pretoria.

8. Wakeel, I. Kafait, U. (2013). Impact of budget deficit on output, inflation and balance of trade. Pakistan: University of Gujrat.

9. World Bank. (1994-2012). Times series for Inflation and Budget Deficit.

10. INSTAT. (1994-2012). Consumer Price Index. 